\title{
Micropropagation and rejuvenation of Sequoia sempervirens (Lamb) Endl: a review
}

\author{
Y Arnaud 1, A Franclet 2, H Tranvan 1, M Jacques 1 \\ 1 Université $P$ et M Curie, Paris VI, Laboratoire de Physiologie du Développement des Plantes, \\ Tour 53, 75252 Paris Cedex 05; \\ 2 Institut de Recherche Agronomique et Forestière, 13 avenue de Champabon, \\ 77520 Donnemarie-Dontilly, France
}

(Received 5 May 1992; accepted 17 December 1992)

\begin{abstract}
Summary - This article describes the botanical, biological and forest-tree characteristics of Sequoia sempervirens, the reasons for interest in its in vitro vegetative multiplication, the difficulty in achieving this from old and remarkable trees, and reviews means of overcoming this limitation. Among such means are the repeated culture of stem fragments on media containing appropriate hormonal combinations, the micrografting of buds originating from old trees onto juvenile rootstocks, and regeneration of buds from previously rejuvenated material. The value and limitations of these protocols and of morphological, physiological and biochemical markers of rejuvenation are discussed. The experimental conditions required for the formation of somatic embryos are described. Increased knowledge of in vitro micropropagation will be essential to enhance the use of clonal selection and offer practical outlets to studies concerning somatic hybridization and somatic embryogenesis.
\end{abstract}

micropropagation / rejuvenation / Sequoia sempervirens / somatic embryogenesis

Résumé - Micropropagation et rajeunissement du Sequoia sempervirens (Lamb) Endl : revue. Cet article présente les principales caractéristiques botaniques, biologiques et forestières du Sequoia sempervirens. II analyse l'intérêt de la multiplication végétative réalisée in vitro soit par micropropagation sensu stricto (figs 1,2 et 3), soit par régénération (figs 6,7 et 9); il discute les raisons de la difficulté à la réaliser à partir d'arbres âgés et remarquables ainsi que les moyens de la contourner. Parmi ces moyens figurent la réitération des cultures de fragments de tige sur des milieux contenant un équilibre hormonal adéquat (tableaux l et II), le microgreffage de bourgeons appartenant à des plantes âgées sur des porte-greffes juvéniles (figs 4 et 5), la régénération de bourgeons à partir de matériel préalablement rajeuni selon l'un des protocoles précédents (figs 10 et 11). L'intérêt et les limites de ces protocoles sont discutés, en considérant les marqueurs morphologiques (figs 12 et 13), physiologiques et biochimiques du rajeunissement. Les conditions d'obtention de l'embryogenèse somatique chez cet arbre sont décrites (fig 8). Finalement, l'accroissement de nos connaissances en micropropagation in vitro apparaît essentiel pour augmenter la qualité de la sélection clonale et offrir des débouchés pratiques aux travaux concernant l'hybridation somatique et l'embryogenèse somatique. L'acquisition de telles connaissances de base devrait permettre une meilleure utilisation de cet arbre. 


\section{INTRODUCTION}

Sequoia sempervirens (Lamb) Endl is distinguished not only by its exceptional vigour and long life, but also by its productivity of quality wood. It is a gymnosperm belonging to the Coniferophytes, order Cupressales, family Taxodiaceae (Stokey, 1981). It is the only species of the genus Sequoia (Chadefaud and Emberger, 1960). The number of chromosomes is $2 n=66$ (Stebbins, 1948), with 1 to 6 accessory chromosomes, according to the population (Libby and McCutchan, 1978). Several cultivars have been registered and commercialized (Redher, 1958; Chaudun, 1977).

\section{Origin and geographical area}

The current genus Sequoia is said to derive from an ancestral complex, a component of which is the genus Rhombostrobus (upper Cretaceous) (LaPasha and Miller, 1981). Sequoia langsdorfii, a fossil species presenting narrow parental links with the current Sequoia sempervirens, is supposed to have disappeared from Europe at the end of the tertiary era (Emberger, 1968).

The natural area of extant Sequoia sempervirens extends from southwest Oregon to California (USA). In the 19th century some specimens were exported to Russia, Great Britain and France (Donnet, 1984).

\section{Morphology and development}

Sequoia sempervirens is an evergreen species, with a thick (up to $25 \mathrm{~cm}$ ), fibrous, deeply furrowed bark. The heart-wood is reddish brown (hence the name 'Redwood' given to this species in California) and is formed of tracheids with bordered pits, frequently biserial or triserial (Jacquiot, 1955). Lacking resinous vessels, the heart-wood is particularly fire-resistant when mature. The long fibers $(\approx 4 \mathrm{~mm})$ in the heart-wood represent 70 to $90 \%$ of its dry weight (Donnet, 1984). The sapwood is white and homogeneous (Rol, 1981).

Sequoia sempervirens is a heteroplastic species. In very young trees, the long axis (long twig) generally bears acicular leaves with an axial phyllotaxy. The short axes (lateral twigs) bear light-green, wide and soft leaves, attached at a right, or nearly right angle on the axis, with crosswiseopposite phyllotaxy.

In adult or old trees the long, soft, lightgreen leaves of the stump sprouts and suckers are similar to those issued from seedlings. In the lower part of the crown, the long and short twigs resemble those of young trees. In the upper part of the crown, the long twigs have squamiform leaves which, in very old trees, look like those of Sequoiadendron; the short twigs are feather-like, with the leathery awlshaped, dark green (sometimes bluish green leaves), which form an almost acute angle with the axis of the twig.

In the northern hemisphere Redwood blooms between November and early March (Boulay, 1989). The monosporangiate inflorescences are in a terminal position on the short twigs (Debazac, 1964). Male cones ( $<10 \mathrm{~mm}$ long) can also be in axillary positions and possess numerous stamens. The female cones are 20 to $25 \mathrm{~mm}$ long, with 15 to 20 woody scales. The seeds weigh on average $4 \mathrm{mg}$ and are brown, elliptical and bordered by a small wing. Germination rate is very variable. Many seeds are often empty, the embryos badly formed or infected by parasites. Viable seeds are stored with difficulty (Donnet, 1984; Bourgkard and Favre, 1989). Germination is epigeous and the plantlet has 2 cotyledons, rarely 3 (Debazac, 1964). 
Sequoia sempervirens grows on podzolic or clay to silty loam soils (Lindquist, 1974) and on limestone-rich soils. It is generally found between 30 and $750 \mathrm{~m}$ above sea level. It requires high humidity, the Californian climate meeting this requirement with frequent fog in summer and abundant rains in winter (Lindquist, 1974). Young sequoia is adversely affected by temperatures $<0^{\circ} \mathrm{C}$, but tolerates tow light intensity (Donnet, 1984).

Juvenile growth is very rapid (Donnet, 1984), and is not seasonally rhythmical. Franclet (unpublished results) has observed a growth arrest in old trees during poor seasons, when the terminal buds become big, round, and covered with green scales. Fruiting generally starts at $\approx 15 \mathrm{yr}$; sometimes, however, fruiting occurs on 2yr-old seedlings when ecological conditions are unfavourable (Franclet, unpublished results).

Sprouts sometimes develop on the trunk, and root suckers have been observed (Libby, personal communication), the root origin of which has been confirmed by the authors. The morphology of the young sprouts and root suckers is typically juvenile.

\section{Value and uses}

In France, Sequoia sempervirens has historically been considered as an ornamental tree, and has not been used in silviculture because of its low germination rate and the susceptibility to cold of the young trees. But in recent years interest has increased in its use in forestry, because of the many old trees which have survived very well the harsh winter of the French atlantic region. These old trees could provide the basis of a foundation population (Donnet, 1984) for a reforestation programme to exploit the industrial value of the species. Its industrial value is that: 1) it rarely suffers from diseases or from attacks by insects (Dufrenoy, 1922; Bull, 1951; Roy, 1966; Gale, 1962) (when young its main enemy is fire (Lindquist, 1974)); 2) its vigour and long life are exceptional: the 2 tallest trees known in the world (ARC 154 and ARC $\left.28^{*}\right)$ belong to this species. The age of a $112-\mathrm{m}$ high and 4.6-m thick tree has been estimated at 2200 years (Lindquist, 1974). In France the storm of 1982, which was of exceptional violence, revealed the extremely good wind-throw resistance of the sequoias (de Champs et al, 1983); 3) its heart-wood is coloured, light (density 0.40 to 0.45 ), easy to work, resistant to bad climatic conditions and to pests. Its phenolic products confer exceptional chemical stability (Gale, 1962). It is utilized as timber for woodwork, industry and horticulture and also for plywood production (Panshin et al, 1964). It has potential value in the paper industry, although stump sprouts are preferred because of the pale colour of the sapwood and its fiber length, which make this wood a choice raw material for pulp produced by the modern CTMP (chemical thermo mechanical pulping) technique, regarded as the pulp of the future by many specialists (eg the Technical Centre of the Paper Industry at Grenoble) (personal communication). Sequoia sempervirens is very well suited for short rotation coppicing, which would provide the stump sprout supply required.

The priority now is to select superior trees from those tested over the course of time in the field for their cold resistance, which is the ecological factor most limiting to its planting in Europe. Rapid, large-scale propagation of these 'plus trees' will re-

\footnotetext{
* $A R C=$ Arcata forest. ARC 154 or ARC 28 = registration No of the tree by the National Geographical Institute of the USA.
} 
quire techniques for vegetative propagation.

\section{Horticultural vegetative propagation}

The superior trees ('elite' trees) identified will be adult, and in many cases very old, which makes vegetative propagation difficult.

Attempts at vegetative propagation by cuttings in California (Becking and Belleto, 1968; Libby and Mc Cutchan, 1978; Libby, 1982) as well as in France (Franclet, 1981), have shown that for cuttings of old sequoias, rooting is difficult, later growth is slow and plagiotropic. For the propagation of such trees, sprouts or suckers must be used (Lindquist, 1974; Franclet, 1981; Poissonnier et al, 1981). Such shoots are rarely available in great numbers under natural conditions, but certain techniques, such as cutting back of the main trunk or root-heating via industrial water (Cormary et al, 1980) can increase their production.

These difficulties have stimulated further research work (Festa and Gambi, 1978; de la Goublaye, 1981; VershooreMartouzet, 1985), encouraged by the demonstration that the species can be cultured in vitro (Ball, 1950; Restool, 1956).

In reviewing the in vitro micropropagation of Sequoia sempervirens, it is necessary to separate micropropagation in sensu stricto from other regeneration strategies.

\section{SENSU STRICTO MICROPROPAGATION}

Micropropagation in sensu stricto consists of the use of miniaturized explants bearing either pre-existing caulinary meristems or meristematic areas of leafy axils (Boulay, 1985). It comprises 3 phases: multiplication by intensive and rapid development of axillary buds, elongation of shoots and rooting of these shoots. Rooting can partly or totally be achieved in vitro. Micropropagation is considered to be successful when acclimatization of the plants ex vitro can be achieved reliably.

\section{Initial studies}

Early studies were conducted by Restool (1956), who studied the dependance of the behaviour of shoot segments from burls on factors such as position of the explant in the stem, weight of the explant, composition of the culture medium, and environmental conditions.

Murashige (1977) later tried to develop a culture medium to increase in vitro micropropagation, and obtained rooted plants from sprouts of adult trees.

Inspired by this work, Boulay (1978) attempted to culture materials taken at different heights from trees of various ages (5, 20,50 and $\approx 100 \mathrm{yr}$ ), and found that only sprout shoots could be cultured. After a reiterated culture sequence on multiplication medium (MM) and on elongation medium (EM), many shoots were obtained which could be rooted ex vitro.

This work provided the foundation for many later studies of importance of the physiological state of the material, on the effect of reiteration of the subcultures, on rooting conditions and on behavior of the cuttings ex vitro.

\section{Sterilization of culture media and disinfection of the material}

Disinfection techniques for excised material must be established by the experimenter for each type of explant (Boulay, 1985). One recommendation (de la Goublaye, 1981; Verschoore-Martouzet, 1985) is to 
coat the transversal sections of the excised stem segments with paraffin to prevent penetration of the disinfectant. In general, the disinfection protocols adopted have included immersion in a commercial solution of sodium hypochlorite or a filtrate of a calcium hypochlorite suspension, preceded in some cases by pretreatments with $10 \%$ hydrogen peroxide (Ball et al, 1978; Ball, 1987), or soaking in liquid soap, followed by rapid dipping in $70^{\circ} \mathrm{GL}$ ethanol (Boulay, 1978), or benlate fungicide solution treatment (Bekkaoui and Tranvan, unpublished results). Before introduction in vitro, explants have generally but not always (Ball, 1987), been rinsed 3 times with sterile distilled water. Infection rates are always high in material from adult or old trees (Boulay, 1978; VerschooreMartouzet, 1985; Bekkaoui and Tranvan, unpublished results). They vary according to the original position of the explant with infections being particularly important on explants originating from the top of the tree (Ball et al, 1978; Franclet, 1981; de la Goublaye, 1981), and with the season of their removal. Infections are less frequent in material explanted in July (de la Goublaye, 1981). For grafted material, the period from March to June is favorable (Verschoore-Martouzet, 1985).
Regarding the meristems, VerschooreMartouzet (1985) found no contamination after using calcium hypochlorite, irrespective of the date of removal and origin of the explant in an 80-yr-old tree. Walker (1986) also found none, even without using disinfection treatment.

\section{Multiplication phase}

Explants used were stem segments (fig $1 a)$, bearing 5 to 8 leaves. The MM culture medium used during the multiplication phase was derived from that of Murashige and Skoog (1962) with auxin and cytokinin added. The media used by different authors have been summarized by Boulay (1989). In our laboratory, the MM multiplication medium used contains BAP $\left(2.210^{-6}\right.$ M) and NAA (5 10-8 M) (tables I, I). The period of culture on $\mathrm{MM}$ varies from 3 to 8 weeks (Boulay, 1978; de la Goublaye, 1981; Fouret, 1987; Tranvan et al, 1991).

After axillary buds had developed (fig $1 b)$, newly formed shoots were isolated and transferred to identical fresh medium for intensive multiplication. They can be transferred to an EM elongation medium (fig 1c), and the obtained stems (fig 1d) divided for multiplication on MM.

Table I. In vitro culture of Sequoia sempervirens: composition of the basal medium.

\begin{tabular}{|c|c|c|c|c|c|}
\hline \multicolumn{4}{|c|}{ Mineral salts } & \multirow{2}{*}{\multicolumn{2}{|c|}{$\begin{array}{l}\text { Organic constituents } \\
\qquad\left(m g \cdot \cdot^{-1}\right)\end{array}$}} \\
\hline \multicolumn{2}{|c|}{ Major elements $\left(m \cdot r^{-1}\right)$} & \multicolumn{2}{|c|}{ Minor elements $\left(\mathrm{mg} \cdot{ }^{-1}\right)$} & & \\
\hline $\begin{array}{l}\mathrm{NH}_{4} \mathrm{NO}_{3} \\
\mathrm{KNO}_{3} \\
\mathrm{CaCl}_{2}, 2 \mathrm{H}_{2} \mathrm{O} \\
\mathrm{MgSO}_{4}, 7 \mathrm{H}_{2} \mathrm{O} \\
\mathrm{KH}_{2} \mathrm{PO}_{4} \\
\mathrm{Na}_{2} \mathrm{EDTA} \\
\mathrm{FeSO}_{4}, 7 \mathrm{H}_{2} \mathrm{O}\end{array}$ & $\begin{array}{c}1650 \\
1900 \\
440 \\
370 \\
170 \\
37.3 \\
27.8\end{array}$ & $\begin{array}{l}\mathrm{H}_{3} \mathrm{BO}_{3} \\
\mathrm{MnSO}_{4}, 4 \mathrm{H}_{2} \mathrm{O} \\
\mathrm{ZnSO}_{4}, 4 \mathrm{H}_{2} \mathrm{O} \\
\mathrm{KI} \\
\mathrm{Na}_{2} \mathrm{MoO}_{4}, 2 \mathrm{H}_{2} \mathrm{O} \\
\mathrm{CuSO}_{4}, 5 \mathrm{H}_{2} \mathrm{O} \\
\mathrm{AlCl}_{3}, 6 \mathrm{H}_{2} \mathrm{O}\end{array}$ & $\begin{array}{l}6.2 \\
22.3 \\
8.6 \\
0.83 \\
0.25 \\
0.025 \\
0.05\end{array}$ & $\begin{array}{l}\text { Thiamine } \\
\text { Myoinositol }\end{array}$ & $\begin{array}{l}0.1 \\
100\end{array}$ \\
\hline
\end{tabular}


Table II. In vitro culture of Sequoia sempervirens: composition of different culture media.

\begin{tabular}{lcccc}
\hline Culture medium & $M M$ & $E M$ & $R M$ & $R E M$ \\
\hline Dilution (d) of the basal medium & $\mathrm{d}=2$ & $\mathrm{~d}=2$ & $\mathrm{~d}=3$ & $\mathrm{~d}=3$ \\
$\begin{array}{l}\text { Growth regulators } \\
\text { NAA } \\
\text { BAP }\end{array}$ & $5 \cdot 10^{-8} \mathrm{M}$ & - & - & - \\
Charcoal $\left(\mathrm{g} \cdot \mathrm{l}^{-1}\right)$ & $2.2 \cdot 10^{-6} \mathrm{M}$ & - & $5 \cdot 10^{-5} \mathrm{M}$ & - \\
Sucrose $\left(\mathrm{g} \cdot \mathrm{l}^{-1}\right)$ & - & 20 & - & - \\
Agar $\left(\mathrm{g} \cdot \mathrm{l}^{-1}\right)$ & 30 & 30 & 30 & 30 \\
\hline
\end{tabular}

Basal medium: see table 1; MM: multiplication medium; EM: shoot elongation medium; RIM: root inducing medium; REM: root expression medium.

The material can be grown under weak lighting and a wide range of temperatures, with a preference for temperatures of $\approx 24^{\circ} \mathrm{C}$.

A multiplication ratio from 3 up to 8 can be achieved at 3 weekly intervals (Boulay, 1985). The ability of the explants to develop axillary buds depends on the chronological age of the mother plant and the original shoot, and on the original position of the material on both the ortet and ramet (Boulay, 1978; de la Goublaye, 1981; Verschoore-Martouzet, 1985). Thus, explants originating from a sucker are more reactive than explants derived from the crown, and for the same sucker the most apical regions (most recently formed) show the best response.

\section{Elongation phase}

An isolated cultured meristem will elongate into a leafy shoot if transferred to a modified Murashige and Skoog (1962) medium without added growth regulator, and without activated charcoal (Walker et al, 1985).

But more generally, axillary buds which develop during the multiplication phase (fig 1b) are isolated and transferred to the EM medium (fig 1c) based on the Murashige and Skoog (1962) formula, again without hormones, but containing activated charcoal (tables I, II). The favourable effect of activated charcoal on growth of Sequoia sempervirens in vitro has been previously reported by Boulay (1978). The time of culture on EM can vary from 4 to 8 weeks (Boulay, 1978; Fouret, 1987; Tranvan et al, 1991).

The behaviour and the morphology of the shoots differ over time according to the physiological state of the material introduced into culture. This state depends primarily on the original position on the mother plant and its chronological age: thus de la Goublaye (1981), comparing the behaviour of 3 topoclones (top and base of the crown, base of the trunk) of clone S5 from a tree aged at least $500 \mathrm{yr}$ (Franclet, 1981), observed that after 1 subculture the topoclone from the top of the crown grew 
lowest. Later Fouret (1987) noticed that the growth of materials cultured in vitro for several years was distinctly slower in a clone (No AFOCEL 78461 = clone II in our laboratory) from a 500-yr-old tree (ARC 154) than in clones from a 1-yr-old (No AFOCEL 83753 = clone J) or 50-yr-old (No AFOCEL $77304=$ clone I) trees.

Fouret (1987) reported that, at the end of the elongation phase, when the initial material was young, the leaves were long, soft and light in colour. Furthermore, the phyllotaxy was of axial type in a clone from a 1-yr-old tree, whereas it was either of axial or crosswise-opposite type in a clone from a 50-yr-old tree, and of crosswiseopposite type or more often distichous type in a clone from a 500-yr-old tree.

After 2 months on EM medium, stems sometimes rooted spontaneously although without any auxin, but no rooting was observed when the material originated from the very old tree (Fouret, 1987).

After a culture on EM of $>3$ months the stems from clone II sometimes showed basal or apically situated outgrowths from which slender shoots might grow (Bekkaoui et al, 1984; Fouret, 1987).

If the period of culture on EM lasted for 4 months or longer (Tranvan, unpublished results) the shoots of the old material (clone II) (fig 2a) rooted spontaneously unless they stopped growing and their apical bud was getting round (fig $2 b$ ), after which, if growth took up again (fig $2 \mathrm{c}, \mathrm{d}$ ), very morphologically different areas were observed to have developed along the stem.

\section{Effect of repeated subcultures}

Although during repeated subcultures according to the MM-EM sequence the material became increasingly reactive (Boulay, 1985), differences in reactivity correlated with the position of explant ori- gin and persisted for a long time. Thus material of sucker origin yielded better results than the inferior branches of the crown and better still than the superior branches (de la Goublaye, 1981). Likewise, the morphology of shoots from the old material (clone II) remained different to that of shoots from the young material (clone $\mathrm{J}$ ) for several months (Fouret, 1987). But after $4 \mathrm{yr}$ of repeated subcultures the clone originating from a shoot of the top of the 80-yr-old NP29 tree (Verschoore-Martouzet, 1985) behaved in morphology and reactivity like the clone obtained from the sucker of the same tree (Franclet, personal communication).

Verschoore-Martouzet (1985) observed that, with NP 29 tree material, shoots developed from stem segments after 3 or 4 subcultures on medium supplemented with cytokinin had orthotropic growth, whereas the shoots which developed initially in vitro were plagiogropic.

Micropropagation using passages through EM (-MM-EM- sequence) avoids the abnormalities of waterlogging and fasciation, which often appear in protocols involving several subcultures on cytokinin containing medium (Fouret, 1987; Boulay, 1989) and increases shoot production.

\section{Rooting and acclimatization phases}

The shoots obtained in vitro can either be rooted directly ex vitro under horticultural conditions, or rooted in vitro prior to acclimatization ex vitro.

\section{Rooting ex vitro}

In the first studies, shoots could not be rooted in vitro, but had to be rooted ex vitro (Boulay, 1978). Later, Poissonnier et al (1981) proposed the use of cold storage of the in vitro shoots and use of specific substrates to improve rooting. 
The improvement of shoot production and the improvement of the ex vitro rooting after repeated subcultures enabled $>200$ clones originated from adult trees selected in various regions of France and California to be multiplied (Franclet et al, 1987). These cuttings were used for the establishment of a mother tree orchard at Guingamp in Brittany, from which orthotropic shoots could be recovered in the longer term by pruning and cutting back operations for commercial production of cuttings.

After observing effects on conventional propagation of the original location of the cuttings on adult trees, de la Goublaye (1981), using an 80-yr-old tree located at Fontainebleau, studied the effects of topophysis on shoot growth habit in vitro during repeated subcultures according to the MM-EM sequence. She found there was a progressive improvement in rooting speed (ex vitro) and, more slowly, in the recovery of orthotropy. However, the topophysical effects did not totally disappear over the period of the subcultures. With one of the topoclones of the Fontainebleau tree the number of subcultures not only affected recovery of orthotropy but also later wood productivity ex vitro (Franclet, unpublished results). A similar result was obtained in an experiment conducted on materials from a 500 -yr-old tree, originating from California.

But despite this progress, the problems of long rooting initiation period, rooting fluctuations according to season and plant material used, persistant plagiotropic growth remained. Consequently studies were undertaken on the effects of in vitro rooting.

\section{Rooting in vitro and acclimatization}

In initial experiments with materials from sprouts of different aged trees, Boulay (1978) obtained an in vitro rooting rate of 5 to $25 \%$ depending on the media used, which were various dilutions of modified Murashige and Skoog (1962) medium with an addition of auxin. Using materials from sprouts of aduit trees, Ball et al (1978) obtained $\approx 20 \%$ of rooted shoots with an orthotropic growth habit after acclimatization, although it has to be emphasized that the sprouts used were physiologically young material (see Rejuvenation).

In an attempt to optimize in vitro rooting, Bekkaoui et al (1984) studied the behavior of material from 2 clones (I and II) obtained from a 50 and 500 year-old tree respectively, using multiplication and elongation techniques similar to those of Boulay (1978). The apical microcuttings removed after the elongation phase were 1 to $2 \mathrm{~cm}$ long and had 8 leaves. Optimal conditions for rooting were found to be: rooting induction ( 1 wk) on a RIM medium supplemented with auxin (NAA $510^{-5} \mathrm{M}$ ); rooting expression (6 wk) on root expression (REM) medium, identical but without auxin (tables I, II) (temperature: +20 to $25^{\circ} \mathrm{C}$ ); daily illumination: $9 \mathrm{~h}\left(100 \mathrm{~W} \mathrm{~m}^{-2}\right)$ for clone I; $9 \mathrm{~h}$ $\left(100 \mathrm{~W} \mathrm{~m}^{-2}\right)+15 \mathrm{~h}$ red $\left(12\right.$ to $\left.15 \mathrm{~W} \mathrm{~m}^{-2}\right)$ for clone II). There was a very distinct difference in reactivity between the 2 clones, with the percentage of rooted explants and the mean number of roots per explant always inferior in the oldest material. The best results obtained were in clone 1, 90\% rooting, with a mean of 6 roots per explant; in clone $\mathrm{II}, 60 \%$ rooting and mean of 3 roots per explant. The material from the $500-y r-$ old tree was also more limited in its ability to adapt to the variety of in vitro culture conditions used. Rooting ability and maintenance of this property under widely varying environmental conditions appeared to characterize juvenility.

In a further work on rooting Walker et al (1985, 1987) applied the following treatments to microcuttings from clones obtained from young and old trees: a root induction phase under dark conditions (5 d); an expression phase ( $35 \mathrm{~d}$ ) under different 
types of lighting; an acclimatization phase under natural light, with additional lighting to give a $16 \mathrm{~h}$ photoperiod. For the young easily rooting material, acclimatization was accelerated when rooting was obtained under a high quantum flux (up to $280 \mu \mathrm{E}$ $\mathrm{m}^{-2} \cdot \mathrm{s}^{-1}$ ). The old material was difficult-toroot, but a high quantum flux increased the rooting rate and number of roots. Under short days, night breaks of red or far red light had no effect. For the older clone acclimatization also depended on the period the rooted shoots were cultured on agar medium. After $10 \mathrm{~d}$ they could be acclimatized with $70 \%$ success rate.

The practice in our laboratory (Fouret, 1987; Fouret et al, 1989; Tranvan et al, 1991) has been to take apical cuttings 6 $\mathrm{cm}$ in length from material maintained in vitro for rooting induction in short days after culture on EM (induction: $1 \mathrm{wk}$; expression: $6 \mathrm{wk}$ ) (fig 3). If the culture period on EM exceeds 3 months, the apical cuttings progressively lose their ability to root ('experimental aging'; Tranvan: unpublished observations). For clone II the number of subcultures has affected in vitro rooting (Arnaud et al, 1987). At present, after $12 \mathrm{yr}$ of repeated in vitro culture, shoots from clone Il often root spontaneously.

\section{REJUVENATION}

Different kinds of aging occur in trees (Fortanier and Jonkers, 1976; Chaperon, 1979). Chronological age is the duration of time since germination. Physiological aging reflected, for example, in rooting ability, is the result of the increase in tree size and complexity. Ontogenetic age reflects the successive phases in development, revealed for example in topophysis (Seelinger, 1924; Franclet, 1983; Boulay, 1987b).

Rejuvenation is a necessary prerequisite for mass propagation, and can be defined as the recovery by old plant material of at least some of the properties of younger material (see Pierik, 1990). Walker (1985) prefered the expression 'rejuvenilization', reserving the expression 'rejuvenation' for the rapid and total recovery of juvenile character, for example in apomictic or zygotic embryo formation (Franclet and Boulay, 1989).

In situ pruning, cutting back or grafting can induce a rejuvenating process (Vershoore-Martouzet, 1985), improving in vitro performance (Franclet, 1981; Franclet et al, 1987). The effect of these techniques is to bring the root system closer to the above ground shoot system (Doorenbos, 1965; Chaperon, 1979; Franclet et al, 1980; Favre, 1980). The role of roots could be to supply cytokinins (Kende, 1964; Itai and Vaadia, 1965; Sitton et al, 1967).

Media containing a cytokinin appear to have a rejuvenation effect (Boulay, 1978; de la Goublaye, 1981). For example, subcultures on a medium supplemented with cytokinin increases the $\mathrm{K} / \mathrm{Ca}$ ratio in materials from an 80-yr-old tree to values characteristic of seedlings. Similarly, the peak 'peroxidase activity/total proteins' increases with the number of subcultures on cytokinin-containing medium (VerschooreMartouzet, 1985; Boulay, 1987b). These ratios are correlated with rooting ability. These results showed that it was logical to consider the in vitro culture as a technique utilizable for attempting to rejuvenate plant material. In addition, this was suggested by Franclet (1981), Nozeran et al (1982), Margara (1982) for various materials.

Several protocols were developed with a double aim:

- to study the conditions and mechanisms involved in the rejuvenation process (basic aim);

- to attempt the recovery of all 'juvenility properties', particularly the orthotropy in material issued from adult or very old trees (applied aim). 


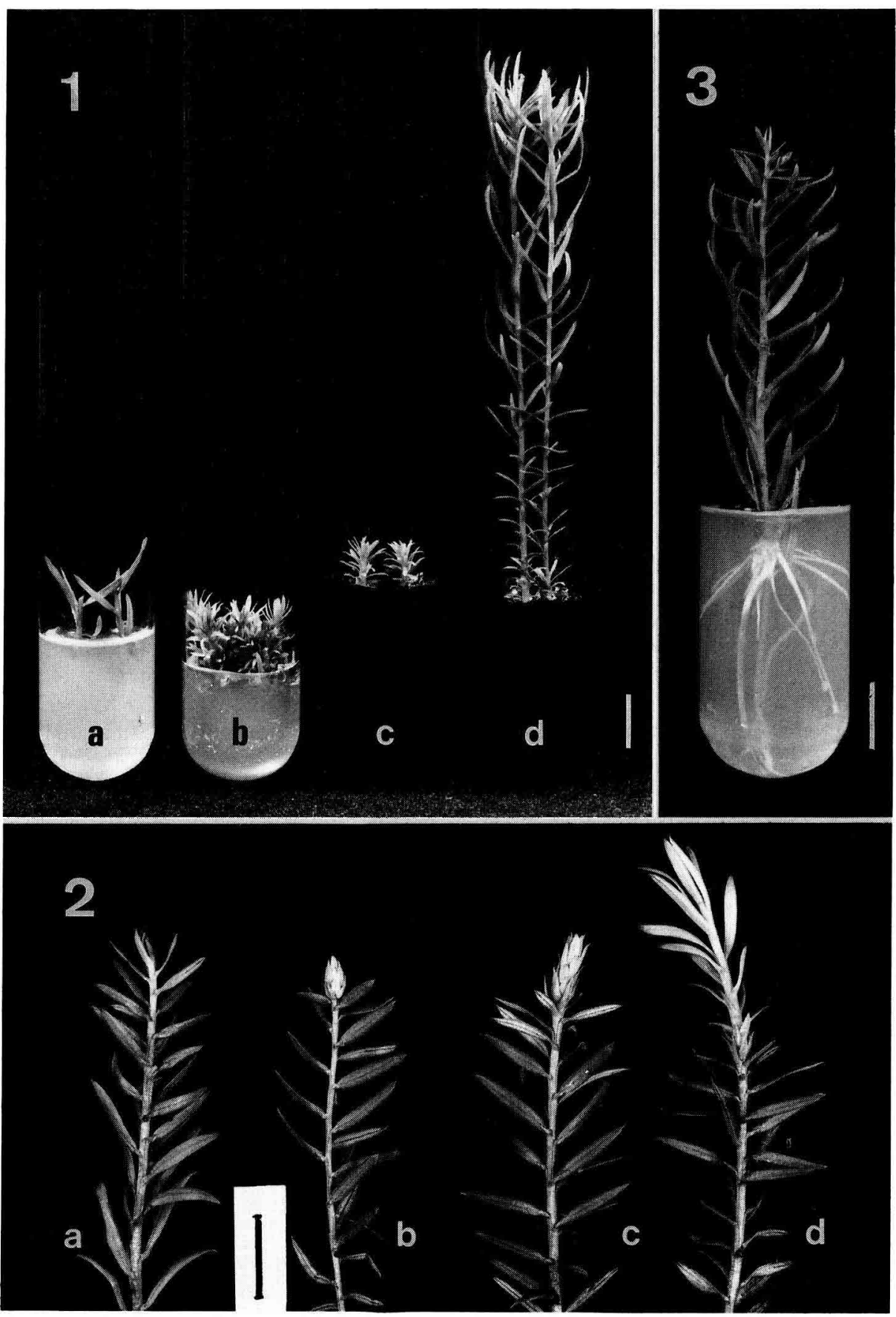




\section{Single or repeated cultures of isolated caulinary meristems (protocol IM)}

Meristems $(0.1 \mathrm{~mm}$ shoot tips, including the meristematic dome with 1 or 2 leaf primordia) were removed (VerschooreMartouzet, 1985) from an 80-yr-old tree at different periods of the year from shoots situated at the base of the tree or at $15 \mathrm{~m}$ height from suckers, or from the same organs grafted onto seedlings, and from seedlings from the same tree. The shoots developed from these meristems were found to recover some juvenile characters after culture on a modified Murashige and Skoog medium with IAA (Boulay, 1989): eg typical juvenile morphology, good rooting ability, partial recovery of the orthotropy. The time of year of removal had little influence, but 'memory' of topophysis was not eradicated.

With repeated subcultures of meristems issued from a very old tree (ARC 154: 500 $y r$, the shoots progressively recovered a young physiological state, evaluated by a better rooting ability (realized ex vitro), by the acquisition of the ability for adventitious budding on isolated leaves and by a better reactivity* of the isolated apical meristems (Walker, 1986). But the plants still maintained plagiotropic growth in the greenhouse. Total (according to the praticians) or ontogenetic (see Schaffalitzky de Muckadell, 1959) rejuvenation of material from a very old tree has thus not yet been achieved.

\section{Micrografting of apices from old material onto young rootstocks (protocol MG)}

The effects have been studied of grafting aged axillary branches apices from unrooted shoots of clone II onto vitroplants of the clone J (Tranvan et al, 1991). The shoots providing the apices were maintained on the EM medium (elongation medium) of the MM-EM sequence for 2,4 or 6 months. The apex $(\approx 4 \mathrm{~mm})$ was grafted onto an oblique section of the rootstock at $1 \mathrm{~cm}$ distance from the roots (fig 4a).

When the grafted apices grew, the scions acquired a growth rate and morphology similar to those of clone $\mathrm{J}$ (fig $4 \mathrm{~b}$ ). Shoots were then excised and submitted to a root inducing treatment according to Bekkaoui et al (1984). Micrografting appeared to increase the number of shoots which rooted, speed of rooting and quality of the root system (fig 4c). After transplanting ex vitro the rooted stems had an orthotropic growth habit for several weeks, but then reverted to plagiotropy. However, a very small number of plants were still orthotropic 2 yr later (fig 5).

Thus micrografting initiated a rejuvenation process. This technique is currently

Figs 1-3. 1. In vitro culture of clone J. Bar $=1 \mathrm{~cm}$. a) Explants: shoot fragments on multiplication medium (MM). b) Axillary buds formed after $8 \mathrm{wk}$. c) Isolated buds transferred to elongation medium (EM). d) Shoots obtained after 8 wk on EM. 2. Effect on the growth of the stems (clone II) of a longer than usual period of culture on EM. Spontaneous cessation ( $a, b)$ of growth and subsequent flush of a shoot tip (c, d). Bar $=1 \mathrm{~cm}$. 3. Induced rooting of a terminal shoot segment (clone J, stock material); observation made $4 \mathrm{wk}$ after the end of the inductive treatment. Bar $=1 \mathrm{~cm}$.

\footnotetext{
- The 'meristem test' is based on the number of days necessary 'to get the cultured meristem green again'.
} 

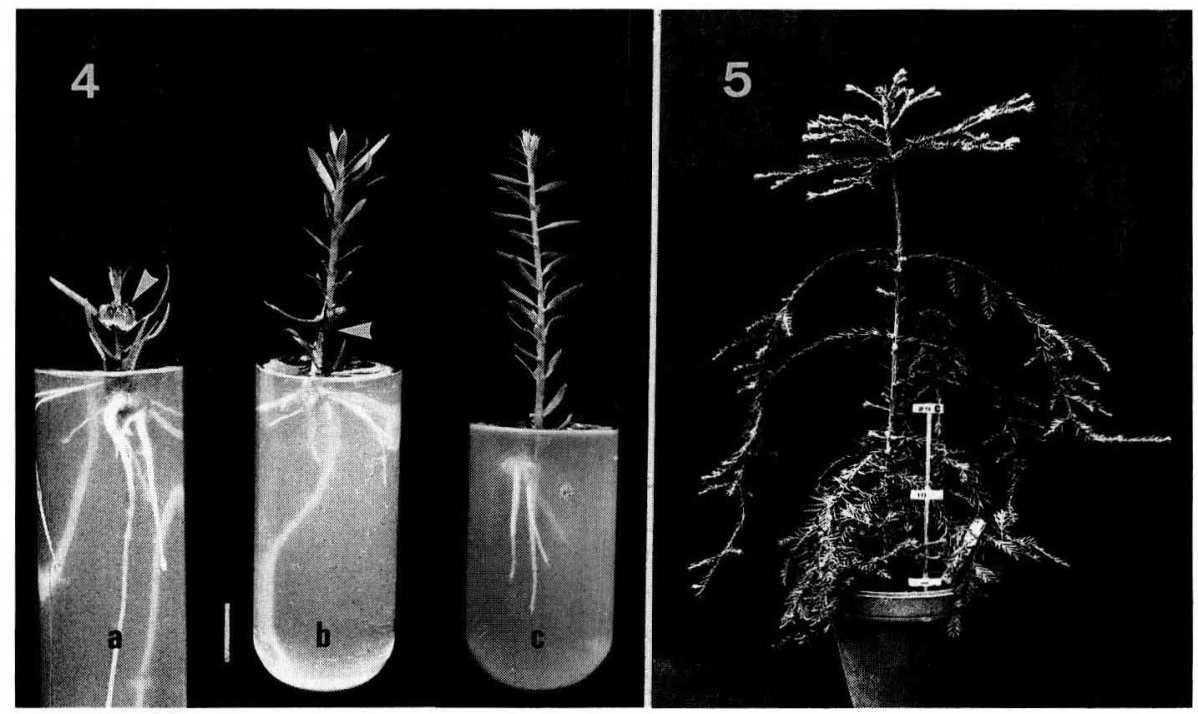

Figs 4-5. 4. In vitro micrografting (the arrow shows the graft). Bar $=1 \mathrm{~cm}$. a) Grafted shoot tip (clone II) onto rootstock (clone J). b) Scion after 5 wk. c) Induced rooting of a scion isolated 8 wk after grafting; $6 \mathrm{wk}$ after the end of the inductive rooting treatment. 5. Orthotropic plant from a rooted scion; observation made 30 months after transfer onto greenhouse.

being improved in our laboratory (Tranvan, unpublished results). The efficiency of this technique was confirmed by Huang et al (1992) who studied morphological and protein markers of rejuvenation status.

\section{Repeated subculture of stem segments (protocol RS)}

Fouret (1987) and Fouret et al (1985, 1986a, 1989) used stem segments with 3 leaves (thus 3 axillary meristematic areas) from different-aged trees (1 yr (clone J), $50 \mathrm{yr}$ (clone I) and $500 \mathrm{yr}$ (clone II)) to study the effect of repeated subcultures. The explants were cultured on MM medium containing BAP $\left(2.210^{-6} \mathrm{M}\right)$ and NAA (5 $10^{-8} \mathrm{M}$ ) or on $\mathrm{MO}$ (same medium as MM but without growth regulator). Eight protocols were tested, differing in frequency of subculturing on 2 different media and in sequence of using these media. Efficiency of rejuvenation of each protocol was evaluated for $18 \mathrm{wk}$ after the start of the culture considering the modifications in a number of properties (Fouret et al, 1985; Franclet et al, 1987): improvement of growth activity of the longest axillary stem, reappearance of a young type phyllotaxy, reduction of the reactivation time of the isolated caulinary meristems, increase in the rate of rooted explants and the reduction of rooting time (Fouret et al, 1985), increase in mean root number per explant, improvement of the quality of the root system. In addition, we observed that the increase of the endogenous IAA/ABA ratio was correlated with rooting ability of the shoots (Fouret et al, 1986b; Fouret, 1987) and another 
criterion was the ability to produce adventitious buds on isolated leaves (Fouret, 1987). The total or ontogenetic rejuvenation is considered as successful when the vitroplants exhibit continuous orthotropic growth after ex vitro transfer (Fouret et al, 1989).

Rejuvenation was more difficult to obtain in clone II than in clone I. The results showed the prime importance of the 'frequences of the subcultures' for the rejuvenation of old material. Frequence of 'one subculture per week' was most efficient, but it was also beneficial to apply a rejuvenation-inducing treatment ( 3 transfers on MM for example), and to conduct the other transfers on MO.

In this work, the juvenile properties appear successively more or less rapidly and more or less clearly according to the proto$\mathrm{col}$ and the physiological state of the initial material. But certain properties of the rejuvenated state may disappear (Arnaud et al, 1989). The rejuvenation - 'rejuvenilization' according to Walker (1986) - appears as a sequence of ability states. The cuttings from the material rejuvenated according to the RS protocol kept a plagiotropic growth habit ex vitro.

Adventitious budding induced on isolated leaves of previously rejuvenated material in one of the protocols produced plants (Fouret et al, 1989) which maintained ex vitro orthotropic growth for $4 \mathrm{yr}$ in the greenhouse and then outdoors. It has been recently observed (Monteuuis-Bon, unpublished results) that the clonal material produced by these epiphyllous buds contained a specific protein profile. Ontogenetic rejuvenation has thus been obtained in clone II from a 500-yr-old tree (ARC 154) with this specific protocol. However, in such experiments it is difficult to distinguish the contribution to shoot growth modalities of material rejuvenation, root system morphology and environmental conditions during the acclimatization process which can greatly influence root system quality. How such rejuvenated material will grow in the long term is uncertain. One of the first trees produced by epiphyllous budding (during the $\mathrm{IM}$ protocol of Walker, 1986) is $5.2 \mathrm{~m}$ tall after 5 seasons compared to $0.70 \mathrm{~m}$ for the control obtained using the technique of Boulay (1978) (Franclet, unpublished results).

These results indicate that several factors control the rejuvenation process: the release of shoot meristems from the correlative control, the repeated subcultures on medium supplemented with cytokinin, and the closeness of the shoot meristem to the root system.

\section{IN VITRO REGENERATION}

Horry-Charrier (1988) isolated protoplasts from foliar tissues of vitroplants in young material and produced microcalli of $\approx 30$ cells, but without regeneration. Regeneration has, however, been obtained by other methods.

\section{Formation of somatic embryos}

Bourgkard and Favre (1988, 1989) obtained somatic embryos in calli on mature zygotic embryos and on cotyledons and hypocotyl segments isolated from vitroseedlings $7 \mathrm{~d}$ after germination. This embryogenesis was only observed when seeds recently collected or stored in a cold room for < 11 to 12 months (darkness; $+4^{\circ} \mathrm{C}$ ). Embryogenic potential in regularly subcultured calli was maintained for only $12 \mathrm{wk}$. In this embryogenesis, no proembryo was observed, and the somatic embryos with typical bipolarous structure were obtained in darkness on culture medium containing $\mathrm{KIN} 2 \mu \mathrm{M}$, BAP $2 \mu \mathrm{M}$ and 
2.4-D $2.5 \mu \mathrm{M}$, without a sequence of media of different composition. The callus obtained was solid and consistent in character, and the somatic embryos were mixed with adventitious buds. On a medium without hormone and under light, the somatic embryo shoots grew, but most of their roots turned brown and developed lateral roots.

In our laboratory (Lefrançois, 1988), neoformed buds (fig 6) (cf Formation of adventitious buds) were isolated from calli from mature zygotic embryos and placed on elongation medium. These buds developed into leafy stems (fig 7), and, from the $\approx 12-\mathrm{cm}$ stems, the ten $1-$ to $3-\mathrm{cm}$ long subapical leaves were removed and put through a double treatment consisting of caulogenetic then callogenetic media (Krogstrup, 1986; Lelu, 1987). On one leaf, a soft translucent white callus was formed which contained very numerous polarized structures (fig 8). Each structure with 2 parts, one with a meristematic cell cluster and the other with long vacuolized cells, is similar in appearance to young zygotic embryos (Singh, 1978). These structures were also similar to the somatic proembryos observed in other gymnosperms (Gupta and Durzan, 1986; Hakman and Fowke, 1987; Lelu et al, 1987).

\section{Formation of adventitious buds}

\section{Female gametophytes}

Plantlets have been regenerated from cultured female gametophytes of Sequoia sempervirens (Ball, 1981, 1987). Mature seeds were excised from green cones which were not yet opened. The cones and then each individual seed were surfacesterilized by soaking in full-strength bleach (Ball, 1987). After removal of testae, the thin layer of female gametophytes (naturally axenic) was isolated from the embryo. After $\approx 2$ months on the culture medium, a callus extruded from the bottom of the gametophyte cavity, where the embryo used to be, with some buds already present. After 6 months' culture (with transfers at monthly intervals) the callus was covered with shoots, which could be removed and grown on other media into orthotropic rooted plants. Many of them have subsequently developed into small trees (Ball, 1987). The chromosome number of the female gametophyte derived plants was 66. Chromosome counts of living female gametophytes of seeds have given various counts; it is assumed that the occasional diploid cells divide to produce the callus from which the buds regenerated (Ball, 1987).

\section{Mature zygotic embryos and isolated cotyledons of these embryos}

Using a protocol similar to that of Lelu et al (1987) with mature embryos and isolated cotyledons, organogenous calli have been found to develop with caulinary neoformations, and in a lower amount with root neoformations (Chiffaudel and Stroobants, 1987). Vascular connections pointed between the caulinary neoformations and the callus tissues. According to Haccius (1978), these buds were adventitious buds and not somatic embryos whose radicular pole would have aborted. After transfer to elongation medium, these buds developed leafy stems, rooting either spontaneously or after induction (RIM-REM treatment). More recently, Tranvan (unpublished results) has observed that adventitious buds can develop on isolated cotyledons without a callus stage (fig 9).

Bourgkard and Favre $(1988,1989)$ also obtained compact organogenic callus on mature entire zygotic embryos or divided young seedlings in which adventitious buds were mixed with somatic embryos, and observed that caulogenesis decreased, as did embryogenesis, with the duration of seed storage at $+4^{\circ} \mathrm{C}$. 

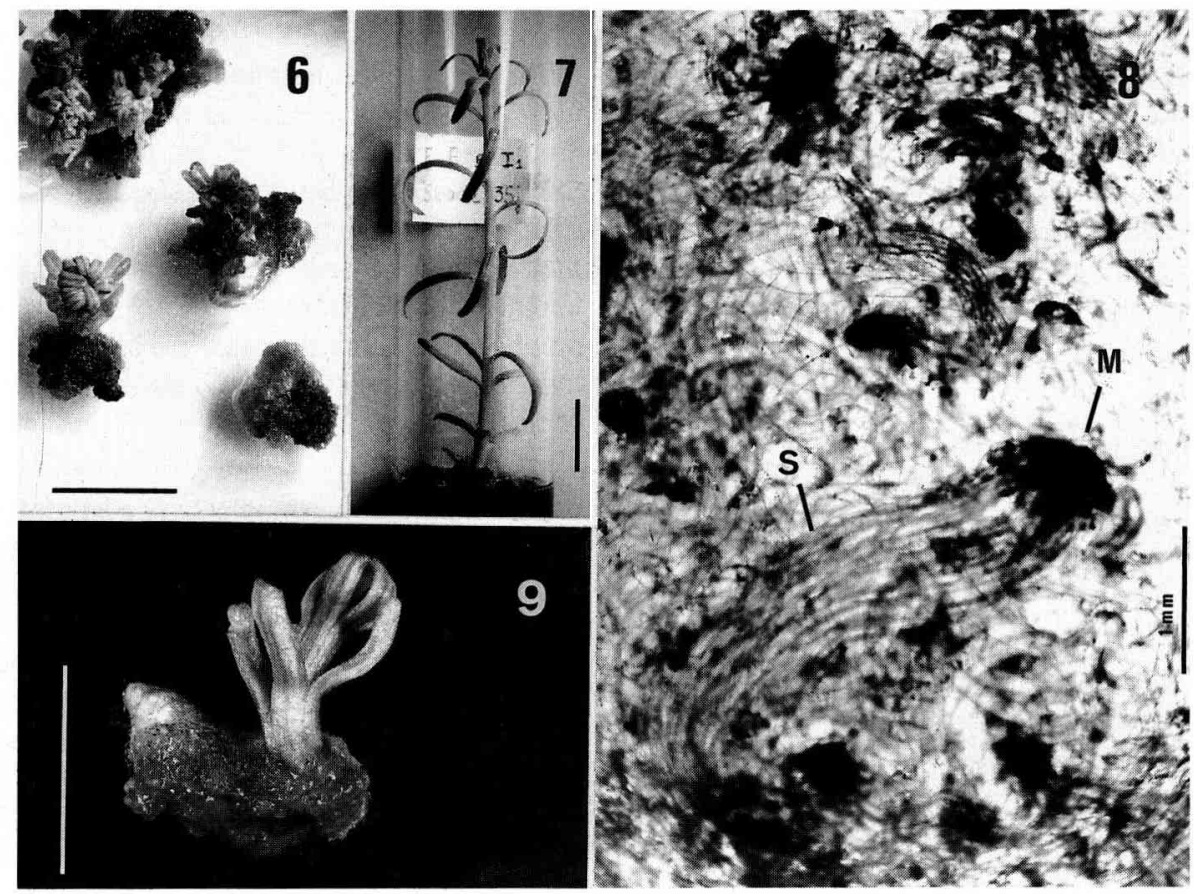

Figs 6-9. 6. Callus and adventitious buds on mature seed embryos. Bar $=1 \mathrm{~cm}$. 7. Shoot on elongation medium (EM), from embryo adventitious bud. Bar $=1 \mathrm{~cm}$. 8. Embryogenic callus on an isolated leaf from the shoot described in figure 7. Stained with orcein. M: cluster of meristematic cells. S: suspensor. 9. Adventitious bud on a mature seed isolated cotyledon explant. Bar $=1 \mathrm{~cm}$.

\section{Stem segments}

Ball (1950) obtained callus capable of regenerating buds from stem segments issued from burls (this was the first in vitro culture in Sequoia sempervirens) and in 1978 Ball et al obtained numerous adventitious buds from juvenile and orthotropic stem segments from the base of an adult tree. These buds developed from cortical proliferating tissues through ruptures in the epidermis into orthotropic shoots which could be rooted and transplanted in the greenhouse. By contrast, plagiotropic stem segments from the crown formed few adventitious buds, and these buds only grew slowly and never produced acclimatized plants.

Ball et al (1978) and Ball (1987) observed that Wolter and Skoog's mineral mixture was better than Murashige and Skoog's medium for regeneration from stem explants (growth regulators were 2.4.5-T and SD 8339). After elongation on a medium lacking cytokinin and containing activated charcoal and auxin, the shoots 
were transferred into rooting medium I (with IBA) for $12 \mathrm{~h}$, and then to rooting medium II (without auxin and with activated charcoal). After $30 \mathrm{~d}$, shoots were transferred to a mixture (2:1:1) of sphagnum moss perlite vermiculite in tubes irrigated with a mineral solution. The tubes were stored in a greenhouse. Ball (1987) advised that a large root system should be established before plantlets were transferred to soil.

\section{Leaves}

Ball et al (1978) and Ball (1987) observed that isolated leaves, cut transversely in half, and laid on culture medium supplemented with cytokinin SD 8339 and auxin 2.4-D, required an intervening callus stage produced on the section surface for regeneration of buds. Nevertheless, adventitious buds have been produced without apparent proliferating callus by:

- maintaining in vitro basal leaves from young material (clone $\mathrm{J}$ ) or, in clones $\mathrm{J}, \mathrm{I}$ and even II, on basal leaves of the stem in contact with the culture medium during RS rejuvenation protocols (Fouret, 1987);

- after specific treatment of subapical (young) isolated leaves from clone II during the rejuvenation protocols IM, Walker, 1986), RS (Fouret, 1987; Fouret et al, 1989) or MG (Tranvan, unpublished results) (fig 10). The epiphyllous bud inducing treatments consisted of 2 stages: induction ( 3 wk) on BM medium (similar to $\mathrm{MM}$ but without NAA and with BAP $1 \mathrm{mg}$. $1^{-1}$ ) and then expression (4 wk) on the BMO medium (similar to BM but without $\mathrm{BAP})$.

Sometimes elongation of such buds is difficult to achieve (Tranvan, unpublished results). Nevertheless the leafy shoots, which grew from epiphyllous buds induced on material of clone II and rejuvenated ac- cording to the type SR protocol (Fouret et al, 1989), rooted easily in vitro after induction and acclimatized easily. They had the morphology of young plants, were vigorous and showed orthotropic growth (fig 11) (cf Repeated subculture of stem segments (protocol RS). By contrast, the nonrejuvenated material of the same clone remained plagiotropic (fig 12), and exceptionally produced male cones on some plants only 21 months after transplanting in the greenhouse (fig 13) (Tranvan, unpublished results).

The adventitious budding technique has great potential for multiplication, but the buds obtained after a callusing stage may not be true-to-type genetic, as Patel and Berlyn (1982) have observed for Pinus coulteri. However, Ball (1987) counted chromosomes in root-tips of Sequoia sempervirens trees regenerated from stem pieces and leaf inocula and found that in both cases the plants are regenerated only from diploid cells.

\section{RECOMMENDED PROTOCOL FOR THE MICROPROPAGATION OF SEQUOIA SEMPERVIRENS}

Regeneration protocols have been detailed by Ball (1987). Described below are our recommended variants to the protocol proposed by Boulay (1989).

\section{Culture establishment}

\section{Choice of initial explant}

Stem pieces should be taken from basal sprouts of an old tree or from actively growing grafted plants grown in the greenhouse. If the explants are taken from the top of an adult or old tree, July is the best period to initiate sterile culture. 

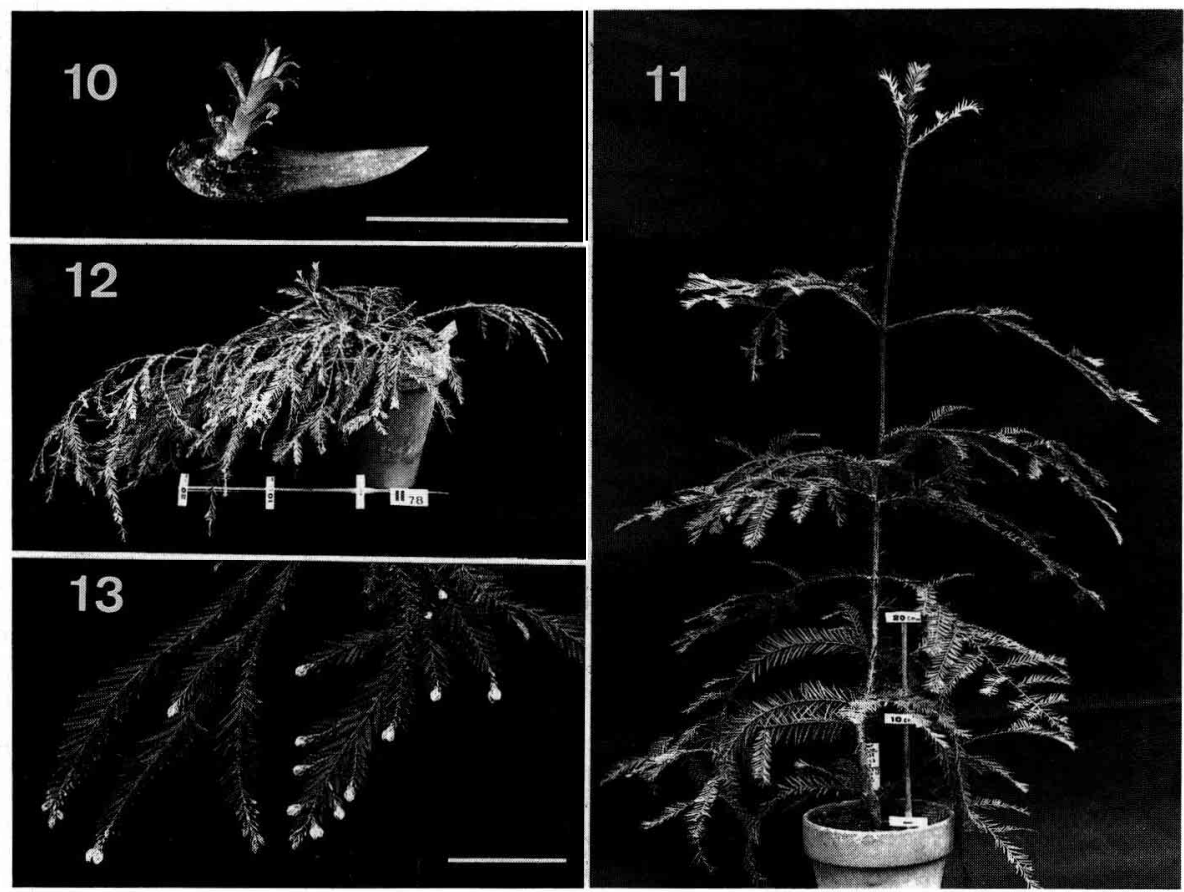

Fig 10-13. 10. Adventitious bud on an isolated leaf of rejuvenated material (clone II; MG protocol). $\mathrm{Bar}=1 \mathrm{~cm}$. 11. Orthotropic plant produced by an adventitious bud induced on an isolated leaf explant from rejuvenated material (clone II; RS protocol); observation made 16 months after transfer into greenhouse. 12. Plagiotropic plant produced by a shoot from non-rejuvenated material (stock material, clone (I); observation made 24 months after transfer into greenhouse. 13. Male cones on a plagiotropic plant produced by a shoot of non-rejuvenated material (stock material, clone II); observation made 21 months after transfer into greenhouse. Bar $=1 \mathrm{~cm}$.

\section{Disinfection and sterilization}

The stem segments should be soaked in benlate solution $(\approx 0.2 \%$, about $24 \mathrm{~h}$ ) or in liquid soap (2 or $3 \mathrm{~min}$ ), rinsed in water and then ethanol at $70^{\circ} \mathrm{GL}$ ( 1 or $2 \mathrm{~min}$ ), soaked in a commercial sodium hypochlorite solution ( 5 to $20 \mathrm{~min}$ ), and finally rinsed 3 times with sterile distilled water.

The duration of these treatments and the concentration of the solutions used depend upon the season, environmental conditions of the mother plant, age, situation on the tree and lignification status of the explant:

\section{Choice of miniaturized explants}

It is recommended to use small, little or non lignified stem segments $(\approx 15 \mathrm{~mm}$ in height with some leaves); or preferably caulinary apices (meristem surrounded by some foliar primordia). 


\section{Multiplication}

Stem segments or meristems are placed in or on multiplication medium (MM) which is composed of half-strength Murashige and Skoog medium as modified by Boulay (1978), NAA (0.01 mg.1-1), BAP (0.5 mg. $\left.\left.\right|^{-1}\right)$, sucrose $\left(30 \mathrm{~g} \cdot \mathrm{I}^{-1}\right)$ and agar $\left(7 \mathrm{~g} \cdot \mathrm{I}^{-1}\right)$.

\section{Elongation}

After 1 or 2 months, the axillary buds (or the very short axillary stems) should be transferred to an elongation medium (EM), similar to MM but without growth regulator and containing activated charcoal $\left(20 \mathrm{~g} \mathrm{l}^{-1}\right)$.

Micropropagation is achieved by using sections (5 or 6 leaves) of vitroshoots, elongated on EM for 1 or 2 months, for culture on MM (several MM-EM cycles).

\section{Rooting and acclimatization (weaning)}

\section{Ex vitro rooting and weaning}

It is recommended to harden the vitroshoots for 1 or 2 wk at a temperature of 5 to $10^{\circ} \mathrm{C}$ under natural light $(10-13 \mathrm{~h}$ illumination). The cuttings should then be soaked for $\approx 24 \mathrm{~h}$ in an auxin solution and transferred to a heated rooting substrate and maintained under a mist system or enclosed in a propagator (photoperiod: $16 \mathrm{~h}$ ).

After 6 to $8 \mathrm{wk}$, the cuttings should be transferred to Melfert 'envelope' and the aerial parts acclimatized by progressive reduction of relative humidity.

\section{In vitro rooting, transfer ex vitro and acclimatization}

Terminal vitrocuttings $\approx 6 \mathrm{~cm}$ high should be taken from shoots elongated on EM.
Rooting induction is achieved by culture on one-third strength Murashige and Skoog medium as modified by Boulay (1978), with NAA (9.3 $\left.\mathrm{mg}^{\circ} \mathrm{I}^{-1}\right)$ (RIM) for $1 \mathrm{wk}$. Rooting expression is achieved on a similar medium without auxin (REM).

Two methods can then be applied:

Method A: Approximately $30 \mathrm{~d}$ after the appearance of the first roots, the vitropiants are transferred ex vitro to a perlite/ vermiculite mixture watered with a mineral nutrient solution (for example, Phytotron solution) (de Bilderling and Lourtioux, 1976) or AFOCEL solution (Poissonnier et al, 1981) and then transferred to a horticultural substrate.

Method B: Approximately $10 \mathrm{~d}$ after the appearance of the first roots, the vitroplants are maintained at cool temperature (eg $22^{\circ} / 12^{\circ} \mathrm{C}$ ) under natural light for $1 \mathrm{wk}$; they are then transferred ex vitro, enclosed in a Melfert 'envelope' and placed on a thick moist cloth maintained at $22^{\circ} \mathrm{C}$ by bottom heat. When roots are visible in the contain$\mathrm{er}$, the plants are transferred to a horticultural substrate.

In both cases, the plastic tent must be gradually removed in order to progressively reduce air moisture.

\section{Rejuvenation}

If rooting of the material is difficult, mother plant material should be submitted to a rejuvenation protocols prior to root induction treatment. Three kinds of in vitro rejuvenation protocols can be used: 1) single or repeated culture(s) of isolated caulinary meristems; 2) single or repeated micrografting (s) of apices from old material onto young rootstocks; 3) repeated subcultures of stem segments.

If the vitroplants remain plagiotropic after transfer ex vitro it is recommended to submit the mother plant material to a reju- 
venation protocol leading to epiphyllous budding. The shoots produced from the epiphyllous buds can then be induced to root, or introduced onto the MM-EM cycle, before rooting induction.

\section{PRACTICAL APPLICATIONS}

These techniques have been in continuous practice for $\approx 14 \mathrm{yr}$, some with clones from very old trees (for example ARC 154, ARC 28).

Boulay (1987a) has reported the AFOCEL micropropagation techniques for the production of rooted clones from 120 selected adult genotypes with a view to reforestation.

The technique of Boulay (1978), later modified in our laboratory, involving alternate subcultures of $\approx 4$ to 8 weeks on a medium containing an auxin and a cytokinin, followed by a medium lacking growth regulator but containing activated charcoal, allows the vitrostems of Sequoia to be maintained and to multiply for period of years without the 'clonal degeneration' found in Douglas fir (Bekkaoui et al, 1986).

By using this technique the rapid miltiplication of $>400$ clones of old trees selected by AFOCEL scientists in parks and gardens of Western Europe (France, England, Ireland, Germany and Belgium) has been effected. It has also facilitated the introduction to Europe of almost all 200 clones of the 'Kuser collection' (a complete sampling of the 'genetic pool' of Sequoia sempervirens in its natural area). It has ensured the multiplication of the conservation collections and accelerated the establishment of planting for clonal evaluation at numerous sites in France.

Some historical or ornamental trees have been commercially propagated using micropropagation eg by RMCV (Recherche, Multiplication, Contrôle des Végé- taux Co) in France. In the USA the Companies Simpson Timber and Georgia Pacific produce vitroplants (Boulay, 1987a) following a scheme initiated by Ball et al (1978) or adopting the technique of Boulay (1978).

\section{PROSPECTS}

The interest of Sequoia sempervirens is recognized in the forestry and paper industry. But future prospects for large-scale micropropagation for reforestation purposes will depend upon economic considerations (the present methods are still too expensive for mass production) and increased basic knowledge of rejuvenation processes. Concerning this last point, the Sequoia sempervirens is considered as good experimental material for studying rejuvenation in woody species (Fouret et al, 1986a; Boulay, 1987b; Franclet et al, 1987). The search for specific gene expression associated with rejuvenation has already started (Bon-Monteuuis, unpublished results; Huang et al, 1992). Moreover, the control of somatic embryogenesis, associated or not with transformation experiments, constitutes an extremely interesting task for the future. Sequoia sempervirens can be considered as a good model for the application of these new biotechnologies to woody species with the aim of improving the production of genetically selected or modified trees.

\section{ACKNOWLEDGMENT}

We would like to thank $\operatorname{Pr} E$ Migniniac for his suggestions during useful talks.

\section{REFERENCES}

Arnaud $\mathrm{Y}$, Al Maarri $\mathrm{K}$, Fouret $\mathrm{Y}$, Larrieu $\mathrm{C}$ (1987) Les régulateurs de croissance exo- 
gènes et endogènes : outils de la micropropagation et marqueurs de l'état physiologique chez les ligneux. In: ANPP Ann $2^{e} \mathrm{Co}-$ loq Substances de Croissance et Leurs Utilisations en Agriculture 1, 101-110

Arnaud $Y$, Fouret $Y$, Larrieu $C$, Tranvan $\mathrm{H}$, Franclet A, Miginiac E (1989) Réflexions sur les modalités du rajeunissement in vitro chez le Sequoia sempervirens. Ann Sci For 46 suppl, 178s-182s

Ball EA (1950) Differentiation in a callus culture of Sequoia sempervirens. Growth 14, 295325

Ball EA (1981) Regenerated plantlets from cultured female gametophytes of Sequoia. In: Collog Int Culture In Vitro des Essences Forestières, IUFRO. Fontainebleau, France, August 31-September 4, 1981; oral commun

Ball EA (1987) Tissue culture multiplication of Sequoia. In: Cell and Tissue Culture in Forestry (Bonga JM, Durzan DJ, eds) Martinus Nijhoff KDR, W Junk Publ 3, 146-158

Ball EA, Morris DM, Rydelius JA (1978) Cloning of Sequoia sempervirens from mature trees through tissue culture: In: In Vitro Multiplica tion of Woody Species. Round-table conference, CRA, Gembloux, Belgium, 181-226

Becking RW, Belleto LO (1968) Vegetative propagation of coastal redwood: rooting of redwood cuttings. In: The Ecology of the Coastal Redwood Forest and the Impact of the 1964 Floods Upon Redwood Vegetation. Suppl Fin Rep NSF Grant 4690. 23 p

Bekkaoui $F$, Arnaud $Y$, Larrieu $C$, Miginiac $E$ (1984) Étude comparative de la rhizogenèse in vitro du Sequoia sempervirens chez deux clones d'âges différents. Ann Rech Sylv AFOCEL 1983. 5-25

Bekkaoui F, Maldiney R, Pilate G, Boulay M, Franclet $A$ (1986) Dégénérescence clonale du Douglas (Pseudotsuga menziesii) cultivé in vitro; relation avec la teneur en éléments minéraux, en auxine, acide abscissique, zéatine et zéatine riboside. CR Acad Sci Paris Sér III 303, 13-17

Bilderling (de) N, Lourtioux A (1976) Quinze années de Phytotronique. In: Études de Biologie Végétale. R Jacques, Paris, 31-342

Boulay M (1978) Multiplication rapide du Sequoia sempervirens en culture in vitro. Ann Rech Sylv AFOCEL, 1977. 38-66
Boulay $M$ (1985) Aspects pratiques de la multiplication in vitro des essences forestières. Ann Rech Sylv AFOCEL, 1984. 7-43

Boulay M (1987a) Conifer micropropagation: applied research and commercial aspects. in: Cell and Tissue Culture in Forestry (Bonga JM, Durzan DJ, eds) Martinus Nijhoff Publ 3, 185-206

Boulay M (1987b) In vitro propagation of tree species. In: Plant Tissue and Cell Culture. Alan R Liss Inc, New York, 367-382

Boulay M (1989) Redwood (Sequoia sempervirens). In: Biotechnology in Agriculture and Forestry 5, Trees // (Bajaj YPS, ed) Springer Verlag, Berlin 549-573

Bourgkard F, Favre JM (1988) Somatic embryos from callus of Sequoia sempervirens. Plant Cell Rep 7, 445-448

Bourgkard F, Favre JM (1989) L'embryogenèse somatique chez Sequoia sempervirens possibilités et limites actuelles. Ann Rech SyIV AFOCEL, 1988. 83-95

Bull RA (1951) A new gall disease of Sequoia sempervirens. In: The Gardener's Chronicle 110-111

Chadefaud M, Emberger L (1960) Traité de Botanique. T. II. Les Végétaux Vasculaires. Masson, Paris, $1539 \mathrm{p}$

Champs de J, Ferron JL, Michaud D, Savatier N (1983) Leçon à tirer de la tempête des 6-8 Novembre 1982. Ann Rech Sylv AFOCEL, 1982. 5-101

Chaperon $\mathrm{H}$ (1979) Maturation et bouturage des arbres torestiers. Études et Recherches AFOCEL 12, 19-31

Chaudun V (1977) Sequoia Endl. In: Le Bon Jardinier. La Maison Rustique, Paris, vol 2, 1576

Chiffaudel I, Stroobants C (1987) Tentatives d'obtention d'embryons somatiques chez le Sequoia sempenirens (Endl). DEA, Université $P$ et $M$ Curie, Paris Vi, $61 \mathrm{p}$

Cormary $Y$, Goglins F, Dumant MJ, Franclet A, Poissonnier $M$ (1980) Production de biomasse et utilisation de rejets thermiques industriels. Ann Rech AFOCEL, 1979. 133-167

Debazac EF (1964) Le sequoia sempervirens. In: Manuel des Conifères. École Nationale du Génie Rural des Eaux et des Forêts, Nancy, France, $113 p$

Detwiler SB (1916) The redwoods: identification and characteristics. Am For 22, 270, 323-328 
Donnet A (1984) Le Sequoia sempervirens : programme de recherche et de développement mené en France par l'AFOCEL. Mém $3^{e}$ année, École Nationale des Ingénieurs des Travaux des Eaux et Forêts et AFOCEL, région Nord-Ouest, $104 \mathrm{p}$

Doorenbos $J$ (1965) Juvenile and adult phases in woody plants. In: Encyclopedia of Plant Physiology, XV/1 (Ruhland W, ed) Springer Verlag, Berlin, 1222-1235

Dufrenoy MJ (1922) Tumeurs de Sequoia sempervirens. Bull Soc Path Vég Fr 9, 148-150

Emberger L (1968) Les Plantes Fossiles Dans Leurs Rapports avec les Végétaux Vivants. Masson, Paris, $758 \mathrm{p}$

Favre JM (1980) Rhizogenèse et bouturage. In: Multiplication Végétative des Plantes Supérieures (Chaussat R, Bigot $G$, eds) GauthierVillars, Paris, 259-277

Festa FP, Gambi G (1978) Variazione stagionale del potenziale rizogeno naturale ed indotto in talee di Sequoia sempervirens Endlicher. Ann Inst Sper Silvic 9, 71-90

Fortanier EJ, Jonkers H (1976) Juvenility and maturity of plants as influenced by their ontogenetical and physiological ageing. Acta Hortic 56, 37-43

Fouret $Y$ (1987) Étude in vitro du rajeunissement préalable à la micropropagation chez le Sequoia sempervirens (Endl): recherche de marqueurs morphologiques, physiologiques et biochimiques. Doctoral thesis, Université $P$ et M Curie, Paris VI, $301 p$

Fouret $Y$, Arnaud Y, Larrieu C (1985) Rajeunissement in vitro du Sequoia sempervirens: effet du nombre et de la fréquence des repiquages; recherche de critères précoces de juvénilité. Ann Rech SyIV AFOCEL, 1984. 111-137

Fouret $Y$, Arnaud $Y$, Larrieu $C$, Miginiac $E$ (1986a) Sequoia sempervirens as an in vitro rejuvenation model. $N Z J$ For Sci 16, 319-327

Fouret $Y$, Arnaud $Y$, Maldiney $R$, Sotta $B$, Miginiac $E$ (1986b) Relation entre rhizogenèse et teneur en auxine et acide abscissique chez trois clones de Sequoia sempervirens (Endl) issus d'arbres d'âge différent. CR Acad Sci Paris Sér III 303, 135-138

Fouret Y, Larrieu C, Arnaud $Y$ (1989) Rajeunissement in vitro chez le Sequoia sempervirens (Endl): recherche du protocole le plus efficace. Ann Rech Sylv AFOCEL, 1988. 5681

Franclet A (1981) Rajeunissement et propagation végétative des ligneux. Ann Rech Sylv AFOCEL, 1980. 11-42

Franclet A (1983) Rajeunissement, culture in vitro et pratique sylvicole. Bull Soc Bot Fr 130 , Act Bot, 87-98

Franclet A, David A, David H, Boulay M (1980) Première mise en évidence morphologique d'un rajeunissement de méristèmes primaires caulinaires de $P$ in maritime âgé ( $P$ inus pinaster Sol). CR Acad Sci Paris Sér $D$ 290, 927-930

Franclet A, Boulay $M$, Bekkaoui $F$, Fouret $Y$, Verschoore-Martouzet B, Walker N (1987) Rejuvenation. In: Cell and Tissue Culture in Forestry (Bonga JM, Durzan DJ, eds) Martinus Nijhoff Publ 1, 232-248

Franclet A, Boulay M (1989) Rejuvenation and clonal silviculture for Eucalyptus and forest species harvested through short rotation. In: Biomass Production by Fast Growing Trees (Pereira JS, Landberg JJ, eds). Kluver Academic, Dordrecht 267-274

Gale AW (1962) Sequoia sempervirens; its establishment and uses in Great Britain. $Q J$ For 56, 126-137

Goublaye de Nantois (de la) $\mathrm{H}$ (1981) Vieillissement et rajeunissement chez le Sequoia sempervirens Endlicher en relation avec la propagation végétative. Thesis, $3^{e}$ cycle, Université $P$ et $M$ Curie, Paris VI, $170 p$

Gupta PK, Durzan DJ (1986) Plantlet regeneration via somatic embryogenesis from subcultured callus of Picea abies (Norway spruce). In vitro Cell Dev Biol 22, 685-688

Haccius B (1978) Question of unicellular origin of non-zygotic embryos in callus culture. Phytomorphology 28, 74-81

Hakman I, Fowke LC (1987) An embryogenic cell suspension culture of Picea glauca (white spruce). Plant Cell Rep 6, 20-22

Horry-Charrier P (1988) Obtention de protoplastes chez Sequoia sempervirens. Ann Rech SyIv AFOCEL, 1987. 49-59

Huang LC, Lius S, Huang BL, Murashige T, Mahdi EFM, Van Gundy R (1992) Rejuvenation of Sequoia sempervirens by repeated grafting of shoot tips onto juvenile rootstocks in vitro. Plant Physiol 98, 166-173 
Itai C, Vaadia $Y$ (1965) Kinetin-like activity in root exudate of water-stressed sunflower plants (Helianthus annuus). Physiol Plant 18, 941-944

Jacquiot C (1955) Atlas d'Anatomie des Bois de Conifères. Centre Technique du Bois, Paris, vol 1, $133 p$

Kende $H$ (1964) Preservation of chlorophyll in leaf sections by substances obtained from root exudate. Science 145, 1066-1067

Krogstrup P (1986) Embryo-like structures from cotyledons and ripe embryos of Norway spruce (Picea abies). Can J For Res 16, 664-668

LaPasha CA, Miller CN (1981) New taxodiaceous seed cones from the Upper Cretaceous of New Jersey. Am J Bot 68, 1374-1382

Lefrançois $C$ (1988) Contribution à l'étude de l'embryogenèse somatique chez le Sequoia sempervirens (Endl). DEA, Université $P$ et $M$ Curie, Paris VI, $45 \mathrm{p}$

Lelu MA (1987) Embryogenèse somatique chez Picea abies $L$ Karst à partir de cotylédons de jeunes plantes. Thesis Université $P$ et $\mathrm{M} \mathrm{Cu}$ rie, Paris VI, $126 \mathrm{p}$

Lelu MA, Boulay M, Arnaud $Y$ (1987) Obtention de cals embryogènes à partir de cotylédons de Picea abies Karst prélevés sur de jeunes plants âgés de 3 à 7 jours après germination. CR Acad Sci Paris Sér III 305, 105-109

Libby WJ (1982) Cloning coast redwoods. Cal Agric 36, 34-35

Libby WJ, McCutchan BG (1978) 'Taming' the Redwood. Am For August 1978, 19-39

Lindquist JL (1974) Redwood, an American Wood. USDA For Serv, Note F 262, $8 \mathrm{p}$

Margara $J$ (1982) Bases de la Multiplication Végétative. INRA, Paris, $262 \mathrm{p}$

Murashige $T$ (1977) Plant tissue culture and its biotechnical application. In: Clonal Crops Through Tissue Culture and its Biotechnological Application (Barz W, Reinhard E, Zenk MH, eds). Springer Verlag, New York, 392-403

Murashige T, Skoog F (1962) A revised medium for rapid growth and bioassays with tobacco tissue cultures. Physiol Plant 15, 473-497

Nozeran R, Ducreux G, Rossignol-Bancilhon L (1982) Réflexions sur les problèmes de rajeunissement chez les végétaux. Bull Soc Bot Fr, Lett Bot 129, 107-130
Panshin AJ, de Zeuw C, Brown HP (1964) Textbook of Wood Technology V. 1. Structure, Identification, Uses and Properties of the Commercial Woods of the United States. Mc Graw Hill, New York

Patel KR, Berlyn GP (1982) Genetics instability of multiple buds of Pinus coulteri regenerated from tissue culture. Can J For Res 12, 93109

Pierik RLM (1990) Rejuvenation and micropropagation. In: Progress in Plant Cellular and Molecular Biology. Proc VIIth Int Congr Plant Tissue Cell Culture. Amsterdam, The Netherlands, June 24-29, 1990, 91-101

Poissonnier M, Franclet A, Dumant MJ, Gautry $Y$ (1981) Enracinement de tigelles in vitro de Sequoia sempervirens. Ann Rech Sylv AFOCEL, 1980. 231-254

Redher A (1958) Sequoia. In: Manual of Cultivated Trees and Shrubs. MacMillan Co, New York, 48

Restool DF (1956) The response of isolated stem segments of Sequoia sempervirens (Lamb) Endl cultured in vitro to various chemical and other environmental treatments. Ph D, Michigan State Univ, $119 p$

Rol R (1981) Séquoias. In: Flore des Arbres, Arbustes et Arbrisseaux. IV: Essences Introduites. La Maison Rustique, Paris, 40-41

Roy DF (1966) Silvical characteristics of redwood. USDA For Serv Res Pap, PSW 28, 1-20

Schaffalitzky de Muckadell M (1959) Investigations on ageing of apical meristems in woody plants and its importance in silviculture. Forstl Forsgsv Dann 25, 307-455

Seelinger R (1924) Topophysis und Zyklophysis Pflanzlicher Organe und ihre Bedeutung für die Pflanzenkultur. Angew Bot 6, 191-200

Singh H (1978) Embryology of Gymnosperms. Gebrüder Borntraeger, Berlin, 192-257

Sitton D, Itai C, Kende H (1967) Decreased cytokinin production in the roots as a factor in shoot senescence. Plant 73, 296-300

Stebbins Jr GL (1948) The chromosomes and relationships of Metasequoia and Sequoia. Science 108, 95-98

Stokey RA (1981) Some comments on the origin and evolution of conifers. Can J Bot 59, 1932-1940 
Tranvan $H$, Bardat $F$, Jacques $M$, Arnaud $Y$ (1991) Rajeunissement chez le Sequoia sempervirens : effets du microgreffage in vitro. Can J Bot 69, 1772-1779

Verschoore-Martouzet B (1985) Étude de la variation topophysique au cours du clonage de Sequoia sempervirens (Endlicher). Thesis, Université P et M Curie, Paris VI, $146 p$

Walker N (1986) Sequoia sempervirens, réjuvénilisation et culture de méristèmes en cascade. Ann Rech Sylv AFOCEL, 1985. 25-47
Walker $N$, Dumas $E$, Franclet A, Bekkaoui $F$ (1985) Technique de cultures in vitro de méristèmes de Sequoia sempervirens et Pinus pinaster. Ann Rech Sylv AFOCEL, 1984. 87-108

Walker N, Jacques R, Miginiac E (1987) Action of light on rooting in vitro and acclimatization of Sequoia sempervirens to soil. Acta horticulturae 212 I. In: Symp In Vitro Problems Related to Mass Propagation of Horticultural Plants (Boxus P, Read PE, O'Riordain F, eds) Gembloux, Belgium, 289-301 